\title{
NUMERICAL DETERMINATION OF LOW PRESSURE GAS INJECTOR FLOW CHARACTERISTICS DEPENDING ON OUTLET NOZZLE DIAMETER
}

\author{
Dariusz Szpica, Andrzej Borawski, Grzegorz Mieczkowski \\ Bialystok University of Technology, Poland \\ d.szpica@pb.edu.pl, a.borawski@pb.edu.pl,g.mieczkowski@pb.edu.pl
}

\begin{abstract}
The paper presents the results of numerical calculations using Computational Fluid Dynamics. The research includes the low pressure gas injector, where the outlet nozzle diameter was adopted as the variable. The gas injector is a component of the alternative fuel supply system for internal combustion engines. It might be used in both liquefied petroleum gas and compressed natural gas supply systems. One of the parameters that can be regulated during the conversion of the engine from the classic to the alternative fuel system is the outlet nozzle diameter, which limits the flow through the injector. If the capabilities of the fuel supply and engine control unit do not give satisfactory results, then the diameter of the injector nozzle might be corrected. The problem is important, because at the moment there is a special emphasis on the composition and overall emissions, therefore the supply system must be efficient and operate with the assumed accuracy. In the article, numerical calculations were carried out using software dedicated to flow calculations, according to the adopted scenario, in terms of specific boundary conditions. For formal reasons, it was necessary to simplify the solid model. Simplifications did not have a significant impact on the final results, but they allowed to reduce the simulation time. Finally, it was decided to validate the results of numerical calculations on a real object. For this purpose, experimental tests were carried out at the original stand using a flow meter, where it was possible to exchange outlet nozzles with different diameter. The results of numerical calculations were compared with the results of experimental studies. There are clear similarities between them, the mean prediction error value was $6.58 \%$. An important feature of numerical calculations is the possibility, apart from quantitative and qualitative assessment, to achieve data, which is difficult or even impossible to gather by the experimental method.
\end{abstract}

Keywords: mechanical engineering, gas injector, research.

\section{Introduction}

The most popular alternative power supply systems for spark-ignition engines in Europe are the liquefied petroleum gas (LPG) systems [1;2]. A sequential vapour phase injection system dominates among them. These are additional fuel systems installed from scratch in the car, which in the control system use the original control signals of the petrol injectors [3]. The control based on the signals from the gasoline Engine Control Unit (ECU) causes that this type of the systems is mostly universal [4]. A continuous development of the petrol supply systems combined with the introduction of direct injection [5] and the emission limitations of vehicles in the approval process [6-9] caused departure from the LPG vapour phase injection systems. However, a large proportion of cars equipped with this type of the power supply systems are still in use, the modifications are constantly carried out. New design solutions are being developed for the low pressure gas injectors, which despite their highly advanced design have functional parameters significantly different from the gasoline injectors. A great expectation is associated with the use of the piezoelectric drives [10-13]. Mathematical models describing the operation of the LPG powered combustion engine are also created, in analytical terms $[14 ; 15]$, as well as using Computational Fluid Dynamics (CFD) [16; 17].

In the general case, the examination of the low pressure gas injectors can be divided into experimental and simulation tests. The experimental methods referring to the flow and functional parameters are presented in [18], electrical parameters in [19; 20], or in terms of overall operation [2123]. Considering the operation specificity of a gas injector, for determining its flow characteristics, the standardised method applicable to petrol injectors can be used $[24 ; 25]$. The results of the experimental research are essential to initiate calculations relating to the functioning of the fuel system [26-29]. The experimental research requires building original test stands equipped with the necessary software, what makes them expensive. In addition, each time it is necessary to build a prototype solution of the injector and test it on the stand $[18 ; 30 ; 31]$. Therefore, the calculation methods are constantly developed, where it is possible to perform the initial testing of the prototypes in virtual conditions. In the calculation methods of the injectors for different fuels, two ways of proceeding are visible. In the first one, own mathematical models of electrical circuits, mechanical part, as well as the flow part are built, modelled on various types of electrovalves [32-37], which requires the introduction of a great number of characteristic coefficients. Solutions of the mathematical dependencies, similarly as in the 
general issues of mechanics, are solved with the use of the dedicated software for analytical or numerical calculations [38-43]. An alternative to this procedure is use of a specialized software, based on the finite element method (FEM) [44-46] or CFD [47-49].

The purpose of the study is to determine numerically the effect of the outlet nozzle diameter on the flow properties of the low pressure gas injectors. In the course of the gas supply system calibration, the base diameter of the outlet nozzle often is increased, thus improving the flow capabilities of the injector. It will be important to determine the functional dependence of the volumetric flow rate on the outlet nozzle diameter by means of computer simulation.

\section{Materials and methods}

The object of the analysis was the Valtek Rail Type 30 low pressure gas injector (Fig. 1). It is a piston-type injector, where the opening is realized by the electromagnetic field of the circuit with a coil. During calibration of the gas supply system, depending on the configuration and demand of the engine, it may be necessary to increase the diameter of the outlet nozzle $d_{n}$.

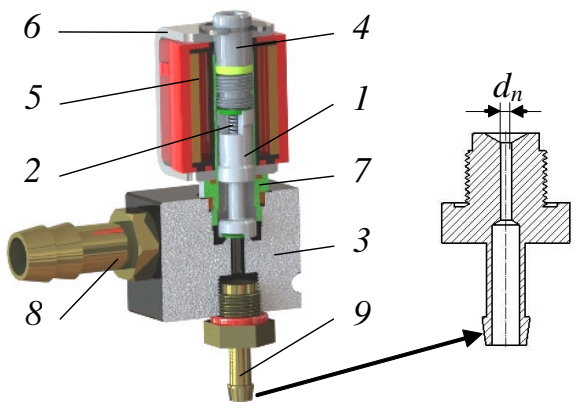

Fig. 1. Valtek Rail Typ 30 gas injector: 1 - plunger; 2 - spring; 3 - corps; 4 - limiter; 5 - coil; 6 - electromagnetic circuit jumper; 7 - pilot; 8 - inlet nozzle; 9 - outlet nozzle; $d_{n}$ - nozzle diameter

Basic technical data of the tested injectors Valtek Rail Typ 30 are presented in Table 1.

Basic technical data of the Valtek Rail Typ 30 gas injector [50]

Table 1

\begin{tabular}{|l|c|c|}
\hline \multicolumn{1}{|c|}{ Parameter } & Unit & Value \\
\hline Coil resistance & $\Omega$ & 3 \\
\hline Plunger displacement & $\mathrm{mm}$ & 0.4 \\
\hline Nozzle size & $\mathrm{mm}$ & $\min .1 .5 /$ max. 3.5 \\
\hline Opening time & $\mathrm{ms}$ & 3.3 \\
\hline Closing time & $\mathrm{ms}$ & 2.2 \\
\hline Max working pressure & $\mathrm{Pa}$ & $4.5 \mathrm{e} 5$ \\
\hline Operating temperature & ${ }^{\circ} \mathrm{C}$ & $-20 \ldots 120$ \\
\hline Operating voltage range & $\mathrm{VDC}$ & 12 \\
\hline
\end{tabular}

The basic equations used for the mathematical description of the flow phenomena related to possibly most general model of fluid (for 3D space) and based on three main principles of mechanics are as follows [51]:

- for the principle of mass conservation (the continuity equation):

$$
\frac{\partial \rho}{\partial t}+\operatorname{div}(\rho u)=0
$$

- for the principle of momentum and angular momentum conservation:

$$
\rho \frac{\partial u}{\partial t}=\rho F+\operatorname{div} S
$$

- for the principle of energy conservation 


$$
\rho \frac{d}{d t}\left(T C_{v}+\frac{u^{2}}{2}\right)=\rho F u+\rho q+\operatorname{div}(\operatorname{Ig} r a d T)+\operatorname{div}(S u)
$$

where $t$-time;

$u$ - fluid velocity;

$\rho$ - fluid density;

$F$ - body force for mass unit;

$S$ - stress tensor;

$C_{v}$ - specific heat capacity with fixed volume;

$T$ - temperature;

$q$ - unit output of internal source of heat;

$\Gamma$ - thermal conductivity.

In numerical calculations, SolidWorks Flow Simulation with a calculation algorithm based on Navier-Stokes equations was used. The equations are complemented by the fluid state equation describing its nature and empirical dependence of the fluid viscosity and thermal conductivity on temperature. It was necessary to create and introduce the geometry, boundary conditions and initial conditions for the investigated case. For the purpose of performing numerical calculations, the model has been simplified within the top part of the plunger, elements not involved in the flow such as the coil, electromagnetic circuit jumper and the spring have been removed (Fig. 2). The boundary conditions for the flow of the medium, which was air, were set at the injector inlet $p_{\text {in }}=1.25 \mathrm{e} 5 \mathrm{~Pa}+p_{a}$, at the outlet $p_{a}=1.01325 \mathrm{e} 5 \mathrm{~Pa}$, the mesh was automatically generated at the level 5 of SolidWorks. At the inlet, the plane for determining goals of the volume flow rate was defined.

a)

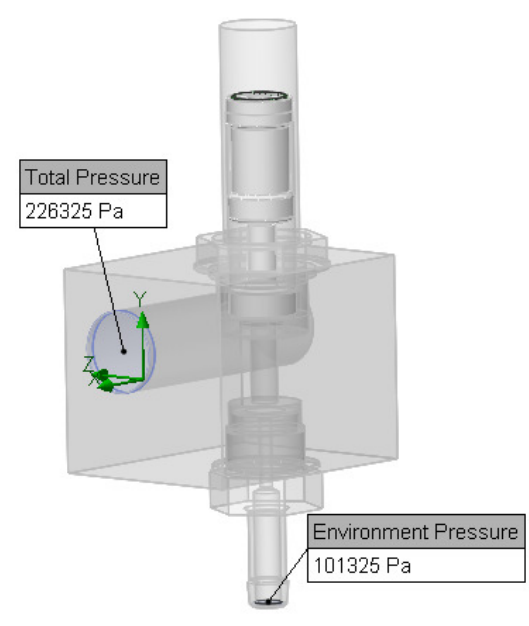

b)

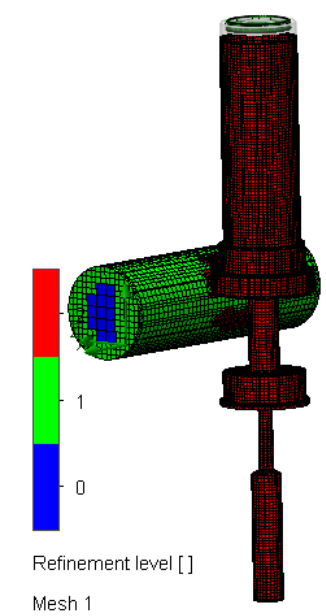

c)

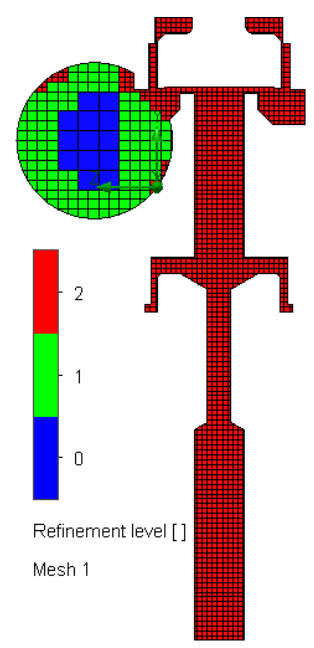

Fig. 2. Model of an injector simplified for the research and boundary conditions (a), mesh (c), analyzed plane (c)

The test stand (Fig. 3) was used to determine the flow characteristics of the gas injectors [31]. Considering the specificity of the gas injector operation, tests at continuous opening describe the maximum possibilities. The injector operates cyclically during operation in the supply system, with a specified frequency and opening time [31]. It is not difficult to model this process in tests, whereas measuring devices, such as flow meters, measure the averaged value over a specific period of time and are not able to assess it per single cycle. Therefore, when using the flow meters, the test shall be performed with a maximum opening in a time period longer than the response time of the flow meter. In determining the flow parameters at the stand (Fig. 3), after filling the buffet tank to a specified pressure and maintaining continuous supply by the air preparation system, full-opening of the research injector was launched using the STAG AC LLC based opening pulse induction system. Using the BRONKHORST F-113AC-M50 flow meter and multimeter, the volumetric flow rate was obtained. 


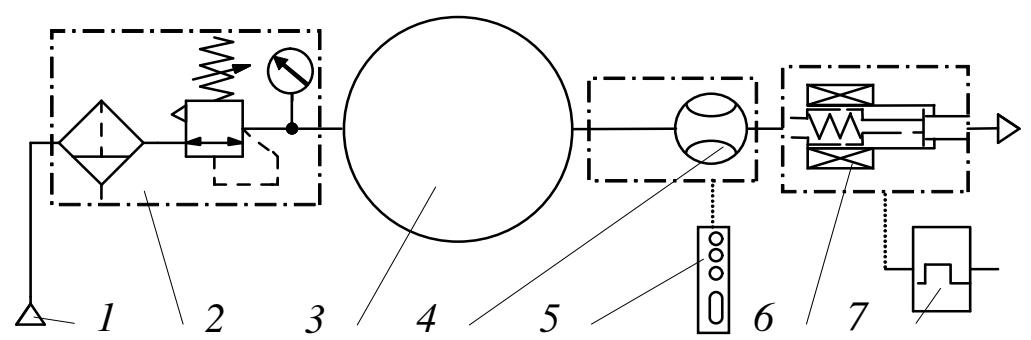

Fig. 3. Structural schematics of the test stand: 1 - air supply; 2 - air preparation system; 3 - buffer tank; 4 - flow meter BRONKHORST F-113AC-M50 (response time < $2 \mathrm{~s}$, range $(0 \ldots .500) \mathrm{l}_{\mathrm{n}} \cdot \mathrm{min}^{-1}$, accuracy $\pm 0.5 \%$ ); 5 - multimeter; 6 - research injector; 7 - STAG AC LLC based opening pulse induction system

\section{Results and discussion}

A series of numerical calculations was conducted for the outlet nozzle diameter (1.5-3.1) mm, with the same boundary conditions and maximum opening of the injector $0.4 \mathrm{~mm}$. Each time the software generated a finite element mesh and searched for established conditions at 89 iterations. The results of the numerical determination are presented in Table 2.

Table 2

Results of the numerical determination

\begin{tabular}{|c|c|c|c|c|}
\hline $\begin{array}{c}\boldsymbol{d}_{\boldsymbol{n}}, \\
\mathbf{m m}\end{array}$ & Fliud cells & $\begin{array}{c}\text { Fluid cells } \\
\text { cont. solids }\end{array}$ & Iterations & $\begin{array}{c}\boldsymbol{Q}, \\
\mathbf{l}_{\mathbf{n}} \cdot \mathbf{m i n}^{-\mathbf{1}}\end{array}$ \\
\hline 1.5 & 49,907 & 26,393 & & 36.938 \\
\hline 1.7 & 50,089 & 26,435 & & 46.880 \\
\hline 1.9 & 50,138 & 26,438 & & 55.661 \\
\hline 2.1 & 50,381 & 26,581 & \multirow{4}{*}{89} & 65.911 \\
\hline 2.3 & 50,576 & 26,625 & & 75.840 \\
\hline 2.5 & 50,716 & 26,675 & & 84.992 \\
\hline 2.7 & 51,024 & 26,771 & & 92.939 \\
\hline 2.9 & 51,276 & 26,813 & & 98.105 \\
\hline 3.1 & 51,508 & 26,859 & & 99.750 \\
\hline
\end{tabular}

Numerical determination beyond the quantification of flow parameters in the form of the volumetric flow rate allows for a qualitative assessment, which cannot be obtained in the experimental studies.
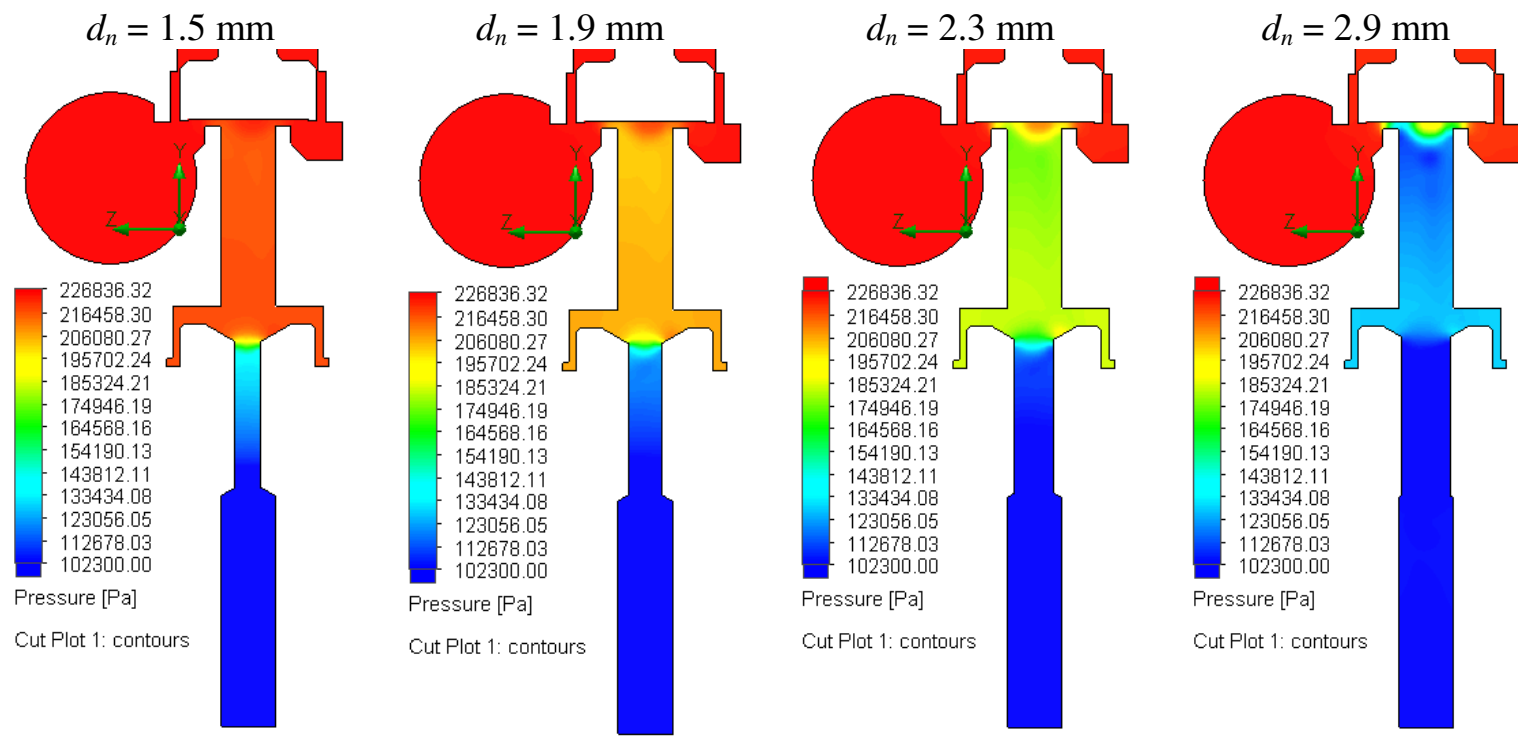

Fig. 4. Results of the numerical determination - pressure in analyzed plane 
Changing the outlet nozzle diameter affects on the pressure distribution in the section injector valve - outlet nozzle in analyzed plane. Increasing the outlet diameter equalizes pressures in this section (Fig. 4). With larger diameters, the opening level of the injector has a greater effect on the flow rate than the nozzle diameter. Unfortunately, increasing the opening level (piston stroke) adversely affects on the opening and closing times, as a result of which the injector cannot realise short injection times. The situation is opposite for the velocity (Fig. 5). Increasing the diameter of the outlet reduces the velocity of the air flow. At larger diameters, an increase in the flow velocity around the injector valve is visible, which confirms the assumption of the dominant influence of the opening level of the injector valve on the outlet nozzle diameter.
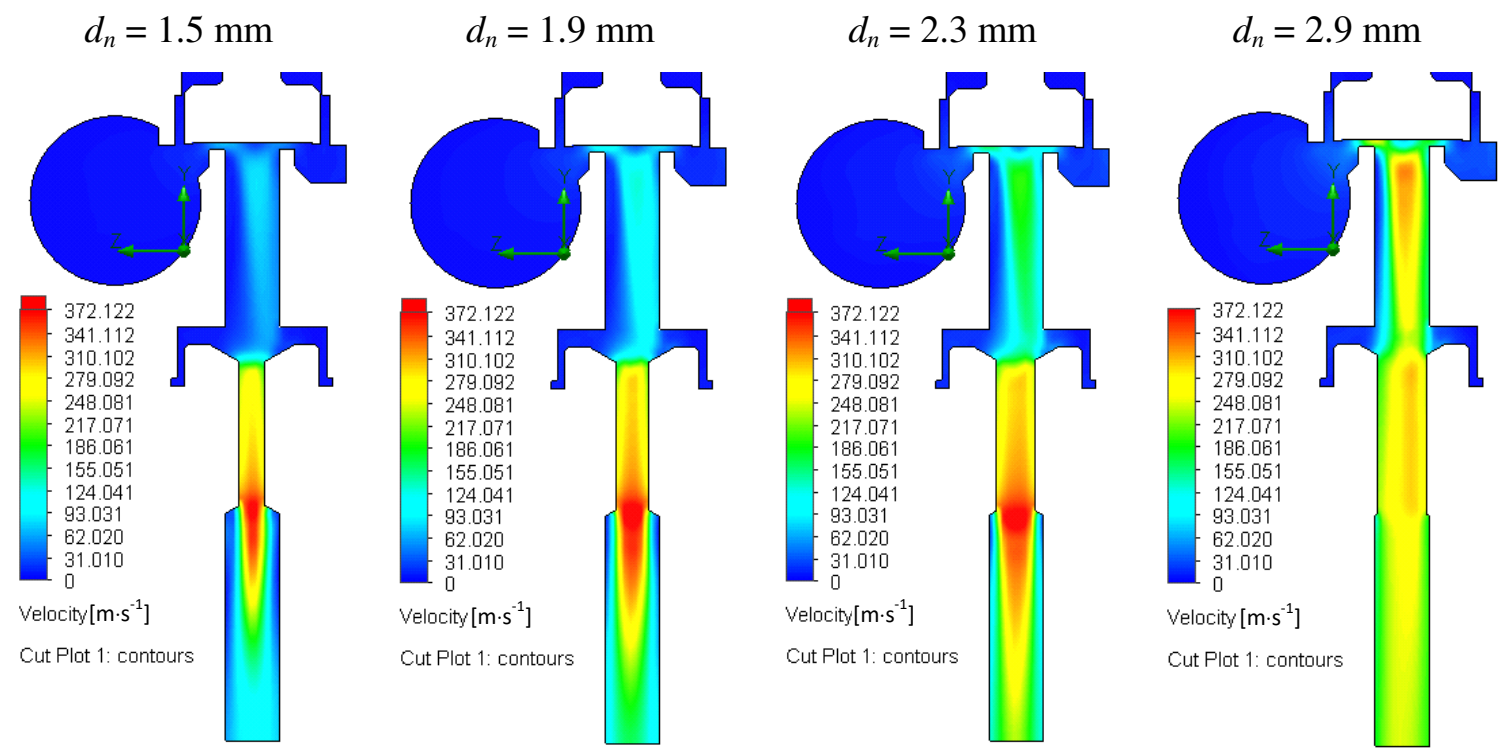

Fig. 5. Results of the numerical determination - velocity in analyzed plane

Subsequently, experimental tests were carried out under the same input conditions as in the numerical determination. The measurement accuracy of the nozzle diameter was $0.01 \mathrm{~mm}$ and the one of the volumetric flow rate $\pm 2.5 \mathrm{l}_{\mathrm{n}} \cdot \mathrm{min}^{-1}$. As it can be seen in the results statement (Fig. 6), numerical determination is not able to model the real conditions. The discrepancy in the middle part of the examined scope is visible, and the character of changes in the volumetric flow rate is more linear. The maximum value of the volumetric flow rate form calculation was $99.750 \mathrm{l}_{\mathrm{n}} \cdot \mathrm{min}^{-1}$, whereas the one from the experimental measurement was $99.602 \pm 2.51_{n} \cdot \mathrm{min}^{-1}$. For comparison, both flow characteristics were approximated using the method of least-squares with a polynomial of 3rd degree, demonstrating a correct match. The coefficient of determination was above $99 \%$. The least-squares method can be easily implemented and the average values of the coefficients represent the trend of change.

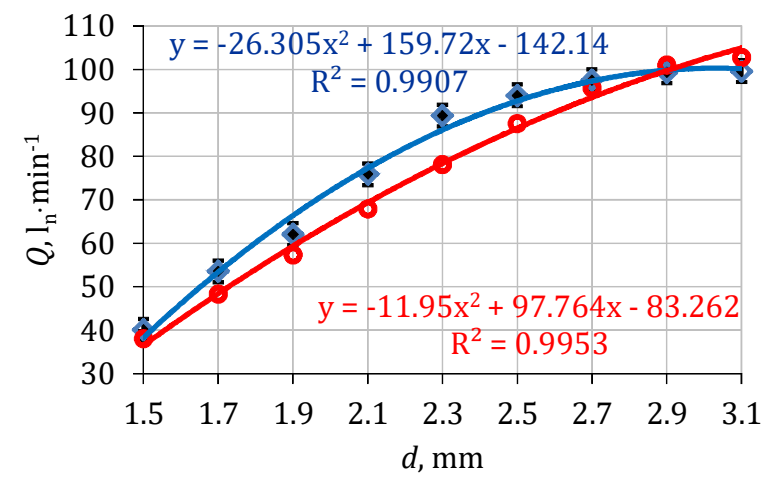

Fig. 6. Results of the experimental validation

In the overall assessment of the validation indicators percentage error $(P E)$ was used: 


$$
P E=100\left|\frac{Q_{\text {mod }}-Q_{\text {exp }}}{Q_{\text {exp }}}\right|, \%
$$

where $Q_{\text {mod }}-$ volumetric flow rate for numerical determination;

$Q_{\text {exp }}$ - volumetric flow rate for experimental determination.

As already mentioned, the greatest discrepancies were obtained in the central part of the examined range, where for $d_{n}=2.3 \mathrm{~mm}$ the maximum error value was $\max P E=12.61 \%$ (Fig. 7). In general, for the whole tested range, the error value was meanPE $=6.58 \%$.

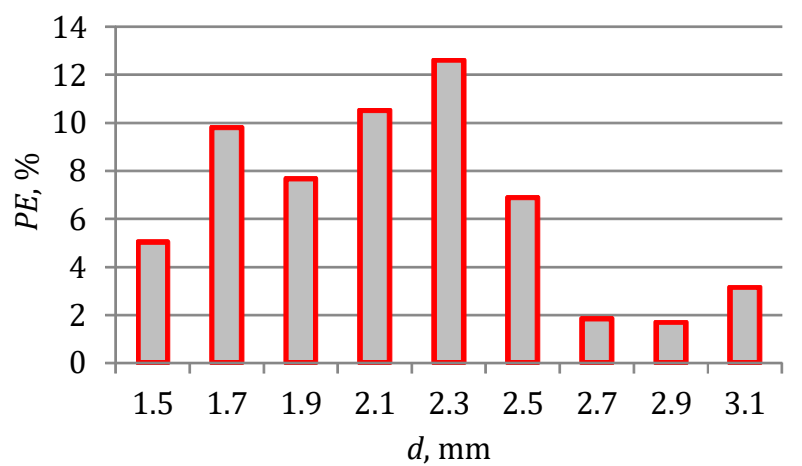

Fig. 7. Percentage error

Basing on the comparison of the flow characteristics (Fig. 6), it should be concluded that further analysis of the influence of various parameters on the numerical determination results is necessary. Primarily it is concerned with the mesh and how to obtain the volumetric flow rate. Obviously, the densification of the mesh gives a more accurate qualitative assessment of the flow, but significantly increases the calculation time. In [51], a method of flow properties assessment based on pressures at selected points of the numerical model was proposed, which could be used as a basis for comparisons with the method presented in this study.

\section{Conclusions}

1. The study presented the numerical determination of the low pressure gas injector flow characteristics depending on the outlet nozzle diameter.

2. The calculations used the SolidWorks Flow Simulation software, where as a base a simplified solid model of the plunger injector was used. The maximum value of the flow rate was $99.7501_{\mathrm{n}} \cdot \mathrm{min}^{-1}$.

3. The flow characteristics determined with a variable outlet diameter were compared with the experimental characteristics (maximum value of the flow rate was $99.602 \pm 2.5 \mathrm{l}_{\mathrm{n}} \cdot \mathrm{min}^{-1}$ ). For the whole tested range, a mean prediction error value was $6.58 \%$.

4. An analysis of pressure and velocity distribution in the selected flow plane was also conducted, indicating the scope of influence of the nozzle diameter and the injector valve lift on the flow characteristics.

5. The determined flow characteristics, both computational and experimental, can be used in the calculation of the alternative fuel supply of the combustion engines.

6. The numerical calculations using computational fluid dynamics are an alternative to experimental research. They do not require building the test stands or real research objects. Functional evaluation is already possible during the prototype design.

\section{Funding}

This publication was financed through the program of the Ministry of Science and Higher Education of Poland named "Regional Initiative of Excellence" in 2019-2022 project number 011/RID/2018/19. 


\section{Acknowledgements}

This research was co-founded through the subsidy of the Ministry of Science and Higher Education for the discipline of Mechanical Engineering at the Faculty of Mechanical Engineering, Bialystok University of Technology.

\section{References}

[1] Raslavicius L., Kersys A., Mockus S. Kersiene N., Starevicius M. Liquefied petroleum gas (LPG) as a medium-term option in the transition to sustainable fuels and transport. Renewable \& Sustainable Energy Reviews, vol. 32, 2014, pp. 513-525.

[2] Mustafa K.F., Gitano-Briggs H.W. Liquefied petroleum gas (LPG) as an alternative fuel in spark ignition engine: Performance and emission characteristics. Proceedings of the International Conference Energy and Environment (ICEE), 2009, pp. 189 - 194.

[3] Wendeker M., Jaklinski P., Czarnigowski J., Boulet P., Breaban F. Operational parameters of LPG fuelled SI engine - comparison of simultaneous and sequential port injection. SAE Technical Paper, 2007, 2007-01-2051.

[4] Borawski A. Modification of a fourth generation LPG installation improving the power supply to a spark ignition engine. Eksploatacja i Niezawodnosc - Maintenance and Reliability, vol. 17(1), 2015, pp. 1-6.

[5] Leduc L., Dubarm B., Ranini A., Monnier G. Downsizing of gasoline engine: an efficient way to reduce CO2 emissions. Oil \& Gas Science Technology, vol. 58(1), 2003, pp. 115-127.

[6] Ristovski Z.D., Jayaratne E.R., Morawska L., Ayoko G.A., Lim M. Particle and carbon dioxide emissions from passenger vehicles operating on unleaded petrol and LPG fuel. Science of the Total Environment, vol. 345, 2005, pp. 93-98.

[7] WLTP lab test. [online] [10.11.2019]. Available at: http://wltpfacts.eu/.

[8] Bielaczyc P., Woodburn J. Trends in automotive emissions legislation: impact on LD engine development, fuels, lubricants, and test methods - a global view, with a focus on WLTP and RDE regulations - Summary of the 6th International Exhaust Emissions Symposium (IEES). Combustion Engines, vol. 174(3), 2018, pp. 56-65.

[9] Commission Regulation (EU) 2017/1154 of 7 June 2017 amending Regulation (EU) 2017/1151 supplementing Regulation (EC) No 715/2007 of the European Parliament and of the Council on type-approval of motor vehicles with respect to emissions from light passenger and commercial vehicles (Euro 5 and Euro 6) and on access to vehicle repair and maintenance information, amending Directive 2007/46/EC of the European Parliament and of the Council, Commission Regulation (EC) No 692/2008 and Commission Regulation (EU) No 1230/2012 and repealing Regulation (EC) No 692/2008 and Directive 2007/46/EC of the European Parliament and of the Council as regards real-driving emissions from light passenger and commercial vehicles (Euro 6). Official Journal of the European Union, L175, 7.7.2017, 708 p.

[10] Mehlfeldt D., Weckenmann H., Stohr G. Modeling of piezoelectrically actuated fuel injectors. Mechatronics, vol. 18, 2008, pp. 264-272.

[11] Pogulyaev Y.D., Baitimerov R., Rozhdestvensky Y. Detailed dynamic modeling of common rail piezo injector. Procedia Engineering, vol. 129, 2015, pp. 93-98.

[12] Mieczkowski G. Criterion for crack initiation from notch located at the interface of bi-material structure Eksploatacja i Niezawodnosc - Maintenance and Reliability vol. 21 (2), 2019, pp. 301310.

[13] Mieczkowski G. Static electromechanical characteristics of piezoelectric converters with various thickness and length of piezoelectric layers. Acta Mechanica et Automatica, vol.13/1(47), 2019, pp. 30-36.

[14] Cao Y., Teng W., Zhang H. Dynamic modeling and hardware-in-the-loop simulation testing for LPG engine. International Conference on Mechatronics and Automation, Harbin, China, 2007, pp. 2093-2098.

[15] Papagiannakis R.G., Hountalas D.T., Rakopoulos C.D. Theoretical study of the effects of pilot fuel quantity and its injection timing on the performance and emissions of a dual fuel diesel engine. Energy Conversion and Management, vol. 48, 2007, pp. 2951-2961, 
[16] Wang B., Li T., Ge L., Ogawa H. Optimization of combustion chamber geometry for natural gas engines with diesel micro-pilot-induced ignition. Energy Conversion and Management, vol. 122, 2016, pp. 552-563.

[17] Jemni M.A., Kantchev G., Abid M.S. Influence of intake manifold design on in-cylinder flow and engine performances in a bus diesel engine converted to LPG gas fuelled, using CFD analyses and experimental investigations. Energy, vol. 36, 2011, pp. 2701-2715.

[18] Szpica D. Comparative analysis of low pressure gas-phase injector's characteristics. Flow Measurement and Instrumentation, vol. 58, 2017, pp. 74-86.

[19]Czarnigowski J. Teoretyczno-empiryczne studium modelowania impulsowego wtryskiwacza gazu. Lublin: Politechnika Lubelska, 2012, 194 p. (In Polish).

[20] Duk M., Czarnigowski J. The method for indirect identification gas injector opening delay time. Przeglad Elektrotechniczny, vol. 88(10b), 2001, pp. 59-63.

[21] Kuroshita K., Sekiguhi Y., Oshiki K., Oneyama N. Development of new test method for flow-rate characteristics of pneumatic components. Paper presented at Bath Workshop on Power Transmission and Motion Control PTMC 2004, Bath, UK United Kingdom, 2204.

[22] Borawski A. Common methods in analysing the tribological properties of brake pads and discs - a review. Acta Mechanica et Automatica, vol. 13(3), 2019, pp. 189-199.

[23] Borawski A. Suggested research method for testing selected tribological properties of friction components in vehicle braking systems. Acta Mechanica et Automatica, vol. 10(3), 2016, pp. 223 226.

[24] SAE J1932 - Low pressure gasoline fuel injector. SAE, 2016, 60 p.

[25] David H.L.S., Harrington D.L., Gandhi A.H., Markle L.E., Parrish S.E., Shakal J.S, Sayar H., Cummings S.D., Kramer J. Gasoline fuel injector spray measurement and characterization - A new SAE J2715 recommended practice. SAE International Journal of Fuels and Lubricants, vol. 1(1), 2009, pp. 534-548.

[26] Liu Z., Ouyang G. Numerical analysis of common rail electro-injector for diesel engine. Proceedings of the International 2009 Conference on Mechatronics and Automation (IEEE), 2009, pp. 1683-1688.

[27] Marcis S., Marcic M., Praunseis Z. Mathematical model for the injector of a common rail fuelinjection system. Engineering. vol. 7, 2015, pp. 307-321.

[28] Mikulski M., Wierzbicki S. Numerical investigation of the impact of gas composition on the combustion process in a dual-fuel compression-ignition engine. Journal of Natural Gas Science and Engineering, vol. 31, 2016, pp. 525-537.

[29] Mikulski M., Wierzbicki S., Pietak A. The multi-phase, zero-dimensional, computational model of a multi-fuel CI engine fueled with gaseous fuel with divided injection of liquid fuel. Eksploatacja i Niezawodnosc - Maintenance and Reliability, vol. 17(1), 2015, pp. $42-48$.

[30] Czarnigowski J., Baranski G., Wendeker M., Duk M., Zyska T. Method to measure injector opening and closing lag times. Combustion Engines, vol. 144(1), 2011, pp. 20-28.

[31] Szpica D. Investigating fuel dosage non-repeatability of low pressure gas-phase injectors. Flow Measurement and Instrumentation, vol. 59, 2018, pp. 147-156.

[32] Lu F., Jensen D. Potential viability of a fast-acting micro-solenoid valve for pulsed detonation fuel injection. 41st Aerospace Sciences Meeting and Exhibit, Aerospace Sciences Meetings, Reno, Nevada, American Institute of Aeronautics and Astronautics, 2003, 2003-0888.

[33] Xiang Z., Liu H., Tao G-L, Man J., Zhong W. Development of an $\varepsilon$-type actuator for enhancing high-speed electro-pneumatic ejector valve performance. Journal of Zhejiang UniversitySCIENCE A, vol. 9(11), 2008, pp. 1552-1559.

[34]Li P.X., Su M., Zhang D.B. Response characteristic of high-speed on/off valve with double voltage driving circuit. IOP Conference Series: Materials Science and Engineering, vol. 220, $2017,012028$.

[35] Chu L., Hou Y., Liu M., Li J., Gao Y., Ehsani M. Study on the dynamic characteristics of pneumatic ABS solenoid valve for commercial vehicle. IEEE Vehicle Power and Propulsion Conference, Arlington, TX, 2007, pp. 641-644.

[36] Demarchi A., Farconi L., Pinto A., Lang R., Romero R., Silva I. Modelling a solenoid's valve movement. In: Akiyama H., Obst O., Sammut C., Tonidandel F. (eds) RoboCup 2017: Robot 
World Cup XXI. RoboCup 2017. Lecture Notes in Computer Science, vol. 11175. Springer, Cham, 2018.

[37] Tian H, Zhao Y. Coil inductance model based solenoid on/off valve spool displacement sensing via laser calibration. Sensors, vol. 18(12), 2018, 4492.

[38] Mieczkowski G., Molski K., Seweryn A. Finite-element modeling of stresses and displacements near the tips of pointed inclusions. Materials Science, vol. 43(2), 2007, pp. 183-194.

[39]Liu Z., Ouyang G. Numerical analysis of common rail electro-injector for diesel engine. Proceedings of the International 2009 Conference on Mechatronics and Automation (IEEE), 2009, pp. 1683-1688.

[40] Liu Y.-F., Dai, Z.-K., Xu X.-Y., Titan L. Multi-domain modeling and simulation of proportional solenoid valve. Journal of Central South University Technology, vol. 18, 2011, pp. 1589-1594.

[41] Pacurar C., Topa V., Munteanu C., Racasan A., Hebedean C., Oglejan R., Vlad G. Solenoid actuator parametric analysis and numerical modeling. Acta Electrotehnica, vol. 56(3), 2015, pp. 246-251.

[42] Brumercik F.; Lukac M.; Caban J.; Krzysiak Z.; Glowacz A. Comparison of selected parameters of a planetary gearbox with involute and convex-concave teeth flank profiles. Applied Science, vol. 10, 2020, 1417.

[43] Marczuk A., Caban J., Aleshkin A.V., Savinykh P.A., Isupov A.Y., Ivanov I.I. Modeling and simulation of particle motion in the operation area of a centrifugal rotary chopper machine. Sustainability, vol. 11(18), 2019, pp. 1-15.

[44] Cheng Q., Zhang Z-D., Guo H., Xie N-L. Simulation and analysis on electro-magnetic-thermal coupling of solenoid GDI injector. International Journal of Applied Electromagnetics and Mechanics, vol. 46(4), 2014, pp. 775-792.

[45] Bensetti M., Bihan Y.L., Marchand C. Development of an hybrid 3D FEM for the modeling of micro-coil sensors and actuators. Sensors and Actuators A: Physical, vol. 129(1), 2006, pp. 207211.

[46] Mieczkowski G., Borawski A., Szpica D. Static electromechanical characteristic of a three-layer circular piezoelectric transducer. Sensors, vol. 20, 2020, 222, 14 p.

[47] Czarnigowski J., Jaklinski P., Wendeker M., Pietrykowski K., Gabowski L. The analyses of the phenomena inside a CNG flap-valve injector during gas flow. Combustion Engines, vol. 1(136), 2009, pp. 10-18

[48] Wendeker M., Jaklinski P., Gabowski L., Pietrykowski K., Czarnigowski J., Hunicz J. Model of CNG flap valve injector for internal combustion engines. Combustion Engines, vol. 4(131), 2007, pp. 42-52.

[49] Czarnigowski J., Wendeker M., Jakliński P., Rola M., Grabowski L., Pietrykowski K. CFD model of fuel rail for LPG systems. JSAE/SAE International Fuels \& Lubricants Meeting, 2007, 200701-2053.

[50] Valtek Type $30-$ technical data. [online] [02.02.2020]. Available at: https://www.valtek.it/en/products/injectors/type-30.

[51] Szpica D. Simplified numerical simulation as the base for throttle flow characteristics designation. Mechanika, vol. 21(2), 2015, pp. 129-133. 